\title{
7 \\ Biographical List of Significant Edinburgh Medical Men referred to in the Main Text
}

\author{
WILLIAM PULTENEY ALISON (1790-1859) \\ MD (Edinburgh) 1811; Professor of the Practice of Physic, 1842-55
}

Sometimes referred to as the "great and the good" Alison, because of his Poor Law agitation and general benevolence towards the needy. He was a nephew of James Gregory $(q . v$.$) and,$ like him, a believer in common sense in medicine as well as philosophy. Had Laycock known Alison actually wanted to keep his clinical professorship and resign the practice of physic teaching only (see Introduction, note 142 above), he might have judged Alison's kindness less of a "monomania" (A, 59). It is not clear whom Alison supported in the contest. Probably, he was loyal to the Bennett-Christison-Syme University party and therefore as active behind the scenes on their behalf as his sense of personal honour would allow.

\section{GEORGE JAMES ALLMAN (1812-1898)}

MD (Oxford) 1847; Professor of Natural History, 1855-70

Successful candidate for the Natural History Chair in 1855, after the death of Edward Forbes. Although technically in the gift of the Crown, in practice it was the Town Council who lobbied the Lord Advocate regarding the preferred candidate. Apparently, Allman got it, despite being a closet Unitarian (A, 62). The Irishman was presented to Senatus on the same day as Wilson (q.v.) the Scot, and Laycock the Englishman. This led to many jokes which, unfortunately, have not been preserved in the historical record.

JOHN HUTTON BALFOUR (1808-1884)

MD (Edinburgh) 1831; Professor of Medicine and Botany, 1845-79

Known as "Woody Fibre" to the students, the Dean seems to have had problems keeping order at Medical Faculty meetings $(\mathrm{A}, 108)$ as well as in the classroom.

\section{JAMES WARBURTON BEGBIE (1826-1876)}

MD (Edinburgh) 1847; Physician-in-Ordinary to Royal Infirmary, 1855-65; ExtraAcademical Lecturer on the Practice of Medicine

Son of James Begbie (1798-1869). Widely respected as a practitioner, he shared the bulk of the lucrative medical consultation market with Christison $(q . v$.). Begbie was also popular as an extraacademical teacher, despite lecturing on the history of medicine. He deputised for Laycock during the latter's illness in 1866-67. Wrote a popular Handy book of medical information and advice in 1860. 


\section{Biographical List}

JOHN HUGHES BENNETT (1812-1875)

MD (Edinburgh) 1837; Professor of the Institutes of Medicine, 1848-75

Had the personality biographers' dreams are made of. As with so many of his Edinburgh contemporaries, the lack of personal papers has inhibited a full length study of his life and career. English born and a stranger to Scottish ways, he came to Edinburgh as a medical student in much the same circumstances as Laycock was to arrive as a professor. However, Bennett soon gained the regard of his peers and the attention of his teachers, and this increased after he followed up his studies with spells in France and Germany. Bennett is credited with furthering French clinical methods in Edinburgh, particularly use of the microscope in diagnosis. A staunch opponent of bloodletting, he published widely on pathological and clinical subjects. Having failed to get the Pathology Chair against Henderson $(q . v$.$) , he consolidated his position as Pathologist to the Infirmary and lectured$ extra-academically. He became Professor of the Institutes of Medicine in 1848, being elected unanimously by the Town Council after his former fellow student, Martin Barry, withdrew because he was unable to sign the required religious Test (See Introduction, note 168 above). Thereafter Bennett exercised his right to give clinical lectures in the University's medical wards. He regarded his step from Institutes to the Practice Chair as a formality. Very little is known about how Bennett responded to the disappointment apart from Laycock's own observations (A, 100). John M'Kendrick, his former assistant and biographer, merely states: "He regarded his defeat as the great disappointment of his life, and there is little doubt it tended to a certain extent to distort his views of men and things" (see Introduction, note 140 above).

WILLIAM SCOTT CARMICHAEL (? - ?)

LRCS (Edinburgh) 1838; Medical Officer Royal Maternity Hospital

Simpson's "Jackal" unleashed to steal morsels of intelligence for the Laycock camp (A, 74). Little is known of his career in Edinburgh.

\section{ROBERT CHRISTISON (1797-1882)}

MD (Edinburgh, 1819); Professor of Materia Medica, 1832-1877

Known by distant admirers as the Nestor of the Scottish medical profession, those who knew him closer at hand probably preferred his other soubriquet "Crafty Bobby" (A, 107). In the professorial harness for over 55 years and an octogenarian, Christison devoted the last few pages of his 'Autobiography' to calculating the average life expectancies of the 68 members of Senatus (including Laycock) who predeceased him! (see Introduction, note 151 above, vol. 1, pp. 422-8). His contributions to medical jurisprudence, toxicology, dietetics and clinical medicine were assessed by his former pupil Gairdner $(q . v$. $)$ who drew attention to Christison's inadequate views on the nature of fevers (see ibid., vol. 2 , pp. 144-9). Although a Tory and therefore in the political minority, he remained one of the City's most sought-after senior consulting physicians. Denying himself the pleasure of 


\section{Biographical List}

replying to public criticism during his lifetime, Christison waited and eventually answered many of his critics in the 'Autobiography'. It contains invaluable, if one-sided, personal reflections on mid-nineteenth-century town and gown relations. After the 1858 reforms, he was a University Court Assessor for many years and had ample opportunities to compare the old with the new. It appears that, like Bennett in 1848 and 1855, and Laycock in 1836 (but not 1855!), he was appalled at having to compete for the Chair of Materia Medica (1832): "I could not have carried the day but through influences quite alien from qualification and without the aid of friends and their devices, such as no man of correct feeling could, without disgust, reconcile himself to see employed" (ibid., vol. 2, p. 14). Unfortunately, he was silent about his own role as a principal friend to Bennett during the campaign.

WILLIAM CULLEN (1710-1790)

MD (Glasgow) 1740; Professor of the Practice of Medicine, 1773-1790

Although Cullen's reputation seems to have suffered in the early years of the nineteenth century, John Thomson's popular biography and his edition of Cullen's works went a considerable way towards rehabilitating him. Like Robert Grant, Laycock saw Cullen as a symbol of the Edinburgh Medical School's pedigree and influence (A, 54). In both its philosophy and scope, Laycock's approach to medicine is surprisingly like Cullen's own.

\section{WILLIAM DICK (1793-1866)}

Founder of Edinburgh Veterinary College

The son of a blacksmith and farrier, Dick was raised in Edinburgh where he studied medicine with Gregory $(q . v$.) and took John Barclay's extra-academical anatomy class. After a brief spell in London, where he qualified as a veterinary surgeon, he returned to found the Edinburgh Veterinary College. He first became involved with the Council in 1835-7, serving as Deacon Convenor of Trades then later as a full councillor. Definitely not one of "Nature's gentlemen," in Laycock's sense (A, 89), Dick was a political radical, a religious sceptic, "rough" in manner and "harsh" of tongue. A supporter of Gairdner originally, his vote eventually went to gentlemanly, peribinkled Tommy $(\mathrm{A}, 87)$.

\section{ANDREW HALLIDAY DOUGLAS (1820-1908)}

MD (Edinburgh) 1840; Physician-in-Ordinary to Royal Infirmary, 1843-52; ExtraAcademical Lecturer on Clinical Diseases

Elected to an Infirmary physicianship at the early age of 24, Douglas helped popularise the use of the stethoscope in Edinburgh. He was a founder of the Medical Missionary Society. He subsequently withdrew from the field when it became clear his support could not be extended beyond the affiliation of his cousin Councillor F. B. Douglas (A, 70). 


\section{Biographical List}

WILLIAM TENNANT GAIRDNER (1824-1907)

MD (Edinburgh) 1845; Pathologist to the Royal Infirmary, 1848-53; Physician-inOrdinary to Royal Infirmary, 1853-62 ; Extra-Academical Lecturer on the Practice of Medicine, 1853-1862

Perhaps the most distinguished of the band of talented medical men trained at the University during the early 1840s. Seen by the University's old guard professors as a musketeer practitioner (Athos), fencing with them for influence over the students in both the Extra-Academical School and Infirmary, alongside the likes of Henry Duncan Littlejohn, (D’Artagnan), J. W. Begbie (q. v.) and W. R. Saunders. A Whig with Unitarian leanings, he became a distinguished pathologist, and a popular teacher of practical medicine. Subsequently, he was made Professor of the Practice of Physic at Glasgow in 1862. Like his influential father, John, President of the Edinburgh College of Surgeons, he also wrote on the history of his profession. Gairdner not only gave his votes to Laycock during the election (A, 85), he appears to have stayed on good terms with him afterwards (See Introduction, note 140 above). Laycock did not attend his farewell dinner.

ROBERT GRAHAM (1786-1845)

MD (Edinburgh) 1808; Professor of Medicine and Botany, 1820-45; Conservator of Royal Botanical Gardens; Physician-in-Ordinary to Royal Infirmary

Remembered fondly by Christison (q.v.) and others as one of the old school physicians who originally translated his Chair from Glasgow to Edinburgh after the death of Daniel Rutherford. He engineered the location of the Royal Botanic Gardens on its present site and served at both the Royal Public Dispensary and the Infirmary, where he gave "solid" if uninspiring clinical lectures with his young colleague, Alison (q.v.).

\section{JAMES GREGORY (1753-1821)}

MD (Edinburgh) 1776?; Professor of the Practice of Medicine, 1790-1821

Viewed by Laycock as another of Edinburgh's distinguished "medical giants", he was probably also aware of the belligerent stance Gregory took with regard to local medical politics, as well as in advocating the common-sense style of physiology of the Conspectus medicinae theoreticae.

WILLIAM HENDERSON (1810-1872)

MD (Edinburgh) 1831; Professor of General Pathology, 1842-69; Physician-in-Ordinary to Royal Infirmary, 1840-43

Removed from Clinical professorship at RIE because of homeopathic tendencies. Known, unfathomably, among students as "Boiler", Henderson got steamed up about the distinction between typhus and relapsing fever. Right condensed on his side rather than Christison's $(q . v)$. 


\section{Biographical List}

JAMES HOME (1758-1842)

MD (Edinburgh) 1781; Professor of the Practice of Physic, 1821-42

Inherited his father's Materia Medica Chair and was duly transferred to Practice of Physic in 1821 after Gregory (q. v.) died. His Toryism ensured his election during a period when political feeling was running high in Edinburgh. Already over sixty by this time, he failed miserably, and this was often alluded to in arguments about the nature of pre-Reform Town Council patronage. He was succeeded by the great and the good Alison (q. v.).

JOHN LIZARS (1787?-1860)

LRCS (Edinburgh); Professor of Surgery at RCSE, 1831-39

Spent a great deal of his life playing Tweedledum to Syme's $(q . v$.) Tweedledee, especially on the piddling subject of Urethrotomy. A supporter and former Councillor, he gave Laycock important advice about how to address the Town Council (A, 72, n 31, n 33).

DOUGLAS MACLAGAN (1812-1900)

MD (Edinburgh) 1833; Professor of Medical Jurisprudence, 1862-97

A well-known Edinburgh Aesculapian poet, many of whose pieces are reproduced in Lays of the colleges, a collection of songs and verses by members of Edinburgh medical clubs and societies.

WILLIAM OVEREND PRIESTLEY (1829-1900)

MD (Edinburgh) 1853; Assistant to J. Y. Simpson

Less of Simpson's jackal and more of the tame poodle, Priestley dutifully did his master's bidding and later edited Simpson's obstetric works. He also acted as a further link with another Laycock supporter, his eventual father-in-law, Robert Chambers. Later rose to great distinction in London obstetric circles, was knighted, and served as M.P. for the Universities of Edinburgh and St Andrews.

JOHN RENTON (? - ?)

LRCS (Edinburgh) 1817; MD (St Andrews) 1839; Town Councillor

An important and influential figure as both proposer of Laycock in the Council election $(A, 87)$ and a subsequent defender of both Laycock and Simpson. However, little is known of his medical and other activities in Pennicuick, Leith and Edinburgh.

JOHN ROBERTSON SIBBALD (? - ?)

LRCS (Edinburgh); 1818 MD (St Andrews) 1825

Another of the medically trained councillors whose Edinburgh career is difficult to trace. 


\title{
Biographical List
}

\author{
ALEXANDER RUSSELL SIMPSON (1835-1916) \\ MD (Edinburgh, 1856); Professor of Midwifery, 1870-1905
}

Helped his uncle with election business while still a student and living at 52 Queen Street (A, 55-6). A. R. succeeded J. Y. as Professor of Midwifery in 1870 and eventually became the new "grand old man" of Scottish obstetrics.

JAMES YOUNG SIMPSON (1811-1870)

MD (Edinburgh) 1832; Professor of Medicine, Midwifery and the Diseases of Children, 1840-70

Once elected to his Chair, Simpson rapidly acquired the largest obstetric practice Scotland had ever seen. Later he enjoyed considerable success as a consulting physician in Britain and Europe. The innovations he made in child birth practices and the infant discipline of gynaecology were legion. Simpson's family tomb bears the words "Nevertheless I Live", and his immortality, in medicine at least, was ensured when he successfully chloroformed most of the medical profession and a significant number of parturient mothers. Simpson took on the "old chairmaker" mantle after the demise of John Thomson, Professor of Medicine and General Pathology, who was one of Simpson's earliest Edinburgh patrons. This youngest son of a Bathgate baker may well have identified with yeoman Laycock's status as an outsider candidate, much as Simpson himself had been in the 1839 midwifery contest. There is scant evidence of how Simpson perceived his dopplegänger role of simultaneously supporting Bennett and Laycock. However, what is available suggests he regarded himself as something of a justified sinner throughout $(\mathrm{A}, 80, \mathrm{n} \mathrm{48,n} \mathrm{50).} \mathrm{This} \mathrm{is} \mathrm{certainly} \mathrm{the}$ approach contended for by Duns, his biographer, who reproduces an undated letter of Simpson's to a Mrs Tootal (see Introduction above, note 154, pp. 358-61). It was written, it appears, soon after Laycock's success became known and is broadly consistent with the Scotsman letters of three years later. Simpson contended he was originally in favour of the reversion scheme $(A, 68-9)$. When this broke down, he worked harder for Bennett than he "would do again for any living man" (on p. 360). Only when he knew Bennett's case hopeless, did he finally side with Laycock because "EVERY common sense man knew, that Dr. Laycock has a majority of either two or three against Wood, if [at the second vote] these were 'pitted"' (on p. 361). In the same letter, Simpson neglected to mention that his early support had probably kept Laycock in the race, and that later he actively arranged the transfer of Bennett's votes to ensure Laycock went into the final round against Wood. The nature of his unremitting opposition to Wood at all stages of the election is unclear, more so as they were religiously and politically allied on other causes.

\section{JAMES SIMSON (1795-1876) \\ MD (Edinburgh) 1816}

A strong Bennett supporter and an Established Church High Tory, he was for many years Surgeon to Edinburgh Prison. His Edinburgh Medical Journal obituary describes him a having a "countenance, full of mingled shrewdness and benignity of expression". 


\section{Biographical List}

JAMES SYME (1799-1870)

FRCS (Edinburgh) 1823; Professor of Clinical Surgery, 1833-69?

Sometimes known as the "Napoleon of Surgery", he enjoyed a European reputation for his innovative work and is still remembered eponymously today for a conservative amputation of the ankle joint. One of the few people ever to get Thomas Carlyle under the knife, he operated privately at home as well as at the Infirmary_possibly even in the same room of Millbank House where he gave away his daughter to Joseph Lister. Given his open hostility to Laycock, it is not surprising that the Englishman went to James Spence for his operation. Summed up by friends, such as Dr John Brown, as "Verax, capax, perspicax, sagax, efficax, tenax", the epigrams Syme attracted from his detractors were quite different (A, 110, n 131). On balance, he preferred orchids to people.

GEORGE WILSON (1818-1859)

MD (Edinburgh) 1839; Professor of Technology and Director of Industrial Museum, 1855-59

Perhaps the one member of the Edinburgh medical community everyone liked and thought highly of-mainly because he gave up all pretensions to practice and devoted himself to chemistry instead. At one point he was Christison's (q. v.) assistant. Bennett once accused him of stealing the remainder of a cod liver oil sample after Wilson had analysed it as a favour (A, 104). Syme took off his foot and he had phthisis like Laycock. Both the professors also shared the common hostility of many colleagues, as it was feared that Wilson's new regius post interfered with preexisting professorships such as Chemistry and Natural Philosophy. In his leisure hours, Wilson wrote religiously inspired poetry and prose and is the subject of a full length biography by his sister, Jessie.

\section{ALEXANDER WOOD (1817-1884) \\ MD (Edinburgh) 1839; Extra-Academical Lecturer on the Practice of Medicine}

As well as leaving Simpson's dinner party early-offended, apparently, by the gaiety of the gathering ( $\mathrm{A}, 78, \mathrm{n} 46)$-Wood retired from extra-academical teaching in final stages of election contest. Gairdner got his room in the College of Surgeons on condition he also purchased Wood's museum for $£ 100$. His champagne breakfast must have been all the more corked as a result (A, 85). Wood was the leading Free Church physician in Edinburgh. In many ways, he was the whig-liberal, extra-academical equivalent of Christison-influential in the College of Physicians as Secretary and later President, on the General Medical Council and a Court Assessor as well. Wood took an interest in the public health of his city and was known for his church-orientated philanthropy towards the poor, having served for many years as a dispensary physician. Apart from his work on pain relief (see Introduction, note 181 above), he wrote against homeopathy and mesmerism. His brother-in-law biographer recorded that his defeat for the Chair was "a great disappointment" and that he almost abandoned medicine for law as a result (See Introduction, note 140 above). He quarrelled with Bennett on several occasions, but appears to have remained on good terms with Simpson, his co-religionist, who organised a public dinner for him in 1861 (ibid., p. 128). Once again, Laycock did not attend. 